\title{
Effectiveness of Educational Intervention Programme on Knowledge Regarding Breast Self Examination Among Higher Secondary School Girls of Biratnagar
}

\author{
Sapkota $D, 1^{1^{*}}$ Parajuli $P_{,}^{2}$ Kafle $T K^{3}$
}

\section{Affiliation:}

1. Milestone Institute of Health, Research \& Development, Biratnagar, Nepal.

2. Professor, Department of Medical-Surgical Nursing, College of Nursing, B.P. Koirala Institute of Health Sciences, Dharan-18, Sunsari, Nepal.

3. Lecture, Department of Community Medicine, Birat Medical College \& Teaching Hospital, Tankisinuwari-02, Morang, Nepal.

\section{ARTICLE INFO \\ Article History \\ Received : 31 Aug, 2016 \\ Accepted : 29 Sept, 2016 \\ Published : 20 Dec, 2016}

(C) Authors retain copyright and grant the journal right of first publication with the work simultaneously licensed under Creative Commons Attribution License CC - BY 4.0 that allows others to share the work with an acknowledgement of the work's authorship and initial publication in this journal.

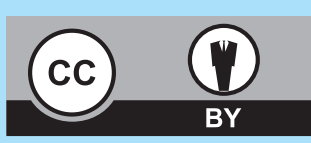

* Corresponding Author

Durga Sapkota

Milestone Institute of Health, Research \& Development Biratnagar, Nepal

Email: durgasapkota9@gmail.com

\section{Citation}

Sapkota D, Parajuli P, Kafle TK. Effectiveness of Educational Intervention Programme on Knowledge Regarding Breast Self Examination among Higher Secondary School Girls of Biratnagar. BJHS 2016; 1 (1) 1:13-19.

\section{ABSTRACT}

\section{Introduction}

Breast self-examination (BSE) is a self-generated, non-invasive and non-irradiative method of breast cancer detection. Self examination of the breasts each month after the menstrual cycle is the simplest yet extremely important way to detect early breast cancer. It has been observed that women can detect $95 \%$ of breast cancers and $65 \%$ of early minimal breast cancers themselves. This method is harmless, less time consuming and can be performed by any woman.

\section{Objective}

To assess the effectiveness of educational intervention programme regarding Breast Self Examination among girl students of study school.

\section{Methodology}

Pre experimental one group pre-test post-test design was adopted for this study. In total, 61 girls were included. The result were analysed by using both descriptive as well as inferential statistics.

\section{Results}

In pre-test $75.4 \%$ had inadequate and only $1.6 \%$ had adequate knowledge regarding Breast Self Examination, in contrast, after the intervention the adequate knowledge was increased to $62.3 \%$. The overall mean score was increased from $33.07 \%$ to $85.14 \%$. The test of significance revealed that the increment in BSE knowledge score due to program intervention was highly significant $(P<0.001)$.

\section{Conclusion}

The educational intervention programme on BSE was found to be highly effective as the knowledge score was significantly increased after intervention of the package among higher secondary school girls.

\section{KEYWORDS}

Breast cancer, examination, school girls 


\section{INTRODUCTION}

Breast cancer is the most common cancer in women worldwide with 1.7 million new cases diagnosed in 2012. This represents about $12 \%$ of all cancer in women and there were 6.3 million women alive who had been diagnosed with breast cancer in the previous five years. Since the 2008 estimates, breast cancer incidence has increased by more than $20 \%$, while mortality has increased by $14 \%$. Incidence has been increasing in most regions of the world but there are huge inequalities between rich and poor countries. Incidence rates remain the highest in more developed regions, however mortality is relatively much higher in less developed countries due to a lack of early detection and access to treatment facilities. ${ }^{1}$

The survival rates of breast cancer differs greatly worldwide, ranging from $80 \%$ or over in North America, Sweden and Japan, to around $60 \%$ in middle-income countries and below $40 \%$ in low-income countries. ${ }^{2}$ In India, breast cancer accounts for $19-34 \%$ of all cancer cases. The Hospital based cancer registry of Nepal has shown in total 2910 cancer patients in the year 2009; among the total cancer cases, 211 (7.2\%) were breast cancer and is the second most commonly diagnosed cancer in Nepal. ${ }^{3}$ Another recent multi hospital based findings reveal that there is shift of breast cancer among young females in Nepal. ${ }^{4}$

Breast Self-Examination (BSE), Clinical Breast Examination (CBE), and Mammography are available preventive technique to detect breast cancer. CBE and Mammography require hospital visit and specialized equipment and expertise whereas BSE is an inexpensive tool that can be carried out by women themselves and highly recommended in developing countries where health facilities are not easily accessible. $^{5}$

Evidences show that women can detect $95 \%$ of breast cancers and $65 \%$ of early minimal breast cancers by themselves and the estimated reduction of mortality by BSE was $18 \%$ and may increase particularly for competent women. ${ }^{6}$ BSE is specifically designed to detect the tumour at an early stage when the small painless lump of cancer is often ignored. Although little is known about the prevention of breast cancer, the chances of survival appears to be good, if it is found early and treated promptly.

BSE or regularly examining breasts by self can be an important way to find a breast cancer at early stage, when it is more likely to be treated successfully. Not every cancer can be found this way, but it is a critical step one can and should take for own self. Regular monthly BSE is an essential health maintenance activity. Teaching skills of BSE can be life saving and with regular performance, malignancy may be discovered at an earlier stage, which can save lives.
Despite an increase in women literacy rate and knowledge about breast cancer, there are certain barriers to practice BSE, like worry about breast cancer, embarrassment, lack of time, unpleasant procedure, lack of privacy, fear of discovering a lump and unfavorable attitude towards Breast Self Examination. ${ }^{7,8,910}$ So, to remove this barrier awareness programmes are showing signs of success, with more women being screened and treated for breast cancer. The objective of this study was to evaluate the effectiveness of Breast Self Examination educational intervention package and its associating factors.

\section{METHODOLOGY}

Quasi experimental one group pre-test post-test study design was adopted to see the effectiveness of the educational package. All girl students of grade 11 and 12 from Marryland Higher Secondary School of Biratnagar city, meeting the eligibility criteria were selected for the study. The intervention package was given to 61 girls among 297 total girls of the school, which accounts about $15 \%$ of total girl population. School was selected by simple random sampling technique and sampling units were selected consecutively. Before, proceeding data collection, ethical approval was taken from ethical review committee of Nobel Medical College and Teaching Hospital, Biratnagar. Permission from the school authority was obtained and oral informed consent was taken from each participants. Standard self-administered questionnaire was developed by consulting the specialists. The tool was pre-tested for reliability on $10 \%$ students in the same school and those subjects were excluded from the final study. Pre-test information was collected before the intervention of educational package on Breast Self Examination. A protocol for educators was designed, BSE related posters, slide, leaflets were used extensively as teaching learning materials and at the end video clip was demonstrated regarding steps of BSE. After 2 weeks of educational intervention, post-test information was collected in same participants with same questionnaire. All the participants who were participated in the pre-test were also participated in the post-test. Data was cleaned and entered in MS Excel 2007 and analyzed using SPSS 17 version. Paired t-test was used to test the significance of effectiveness and independent sample t-test and one way ANOVA were used to test the associating factors.

\section{RESULTS}

Assessment of knowledge on BSE before and after intervention was done and in addition socio-demographic determinants were explored. Table 1 reveals that among 61 respondents, majority of respondents were from age 
group 17-19 years, consisting of $65.6 \%$ and the mean age was $16.62 \pm 1.19$ years. Majority of respondents (70.5\%) were from grade 12 . The Hindu religion was followed by $96.7 \%$ respondents and majority of respondents (55.7\%) belonged to upper high caste. While observing the educational status of respondents' parents, higher proportions (32.8\%) of mothers had completed secondary level education and $29.5 \%$ fathers had also completed same level of education. Similarly, $47.5 \%$ of respondent's fathers were engaged in business occupation; in contrast, $82 \%$ mothers were housewives. The Mean income of the family was reported NRs $18788.5 \pm 11307.5$.

Table 1: Socio-demographic profile of the respondent

\begin{tabular}{|c|c|c|c|}
\hline Characteristics & Category & Frequency & Percentage \\
\hline \multirow{2}{*}{ Age } & $14-16$ years & 21 & 34.4 \\
\hline & $17-19$ years & 40 & 65.6 \\
\hline \multicolumn{4}{|c|}{ Mean \pm SD $=16.62 \pm 1.192$} \\
\hline \multirow{2}{*}{ Level of Education } & Class 11 & 18 & 29.5 \\
\hline & Class 12 & 43 & 70.5 \\
\hline \multirow{2}{*}{ Religion } & Hindu & 59 & 96.7 \\
\hline & Buddhist & 2 & 3.3 \\
\hline \multirow{4}{*}{ Ethnicity } & Upper High Caste & 34 & 55.7 \\
\hline & $\begin{array}{l}\text { Relatively Advantaged } \\
\text { Janajati }\end{array}$ & 7 & 11.5 \\
\hline & $\begin{array}{l}\text { Non-Advantaged } \\
\text { and Others }\end{array}$ & 9 & 14.8 \\
\hline & $\begin{array}{l}\text { Non Advantaged } \\
\text { Janajati }\end{array}$ & 11 & 18.0 \\
\hline \multirow{5}{*}{ Mother's Education } & Illiterate & 10 & 16.4 \\
\hline & Literate & 10 & 16.4 \\
\hline & Primary Level & 13 & 21.3 \\
\hline & Secondary Level & 20 & 32.8 \\
\hline & $\begin{array}{l}\text { Higher Secondary } \\
\text { and Above }\end{array}$ & 8 & 13.1 \\
\hline \multirow{4}{*}{ Father's Education } & Literate & 17 & 27.9 \\
\hline & Primary Level & 11 & 18.0 \\
\hline & Secondary Level & 18 & 29.5 \\
\hline & $\begin{array}{l}\text { Higher Secondary } \\
\text { and Above }\end{array}$ & 15 & 24.6 \\
\hline \multirow{3}{*}{ Mother's Occupation } & Service & 5 & 8.2 \\
\hline & Business & 6 & 9.8 \\
\hline & Housewife & 50 & 82.0 \\
\hline \multirow{3}{*}{ Father's Occupation } & Farmer & 11 & 18.0 \\
\hline & Service & 21 & 34.5 \\
\hline & Business & 29 & 47.5 \\
\hline \multirow{5}{*}{ Family Income } & NRS 5000 - 10000 & 8 & 13.1 \\
\hline & NRS 10001 - 15000 & 10 & 16.4 \\
\hline & NRS 15001 - 20000 & 18 & 29.5 \\
\hline & NRS 20001 - 25000 & 19 & 31.1 \\
\hline & NRS 25001 and Above & 6 & 9.8 \\
\hline \multicolumn{4}{|c|}{ Mean \pm SD $=18788.52 \pm 11307.50$} \\
\hline
\end{tabular}


Figure 1: Frequency distribution of respondents according to sources of information regarding BSE

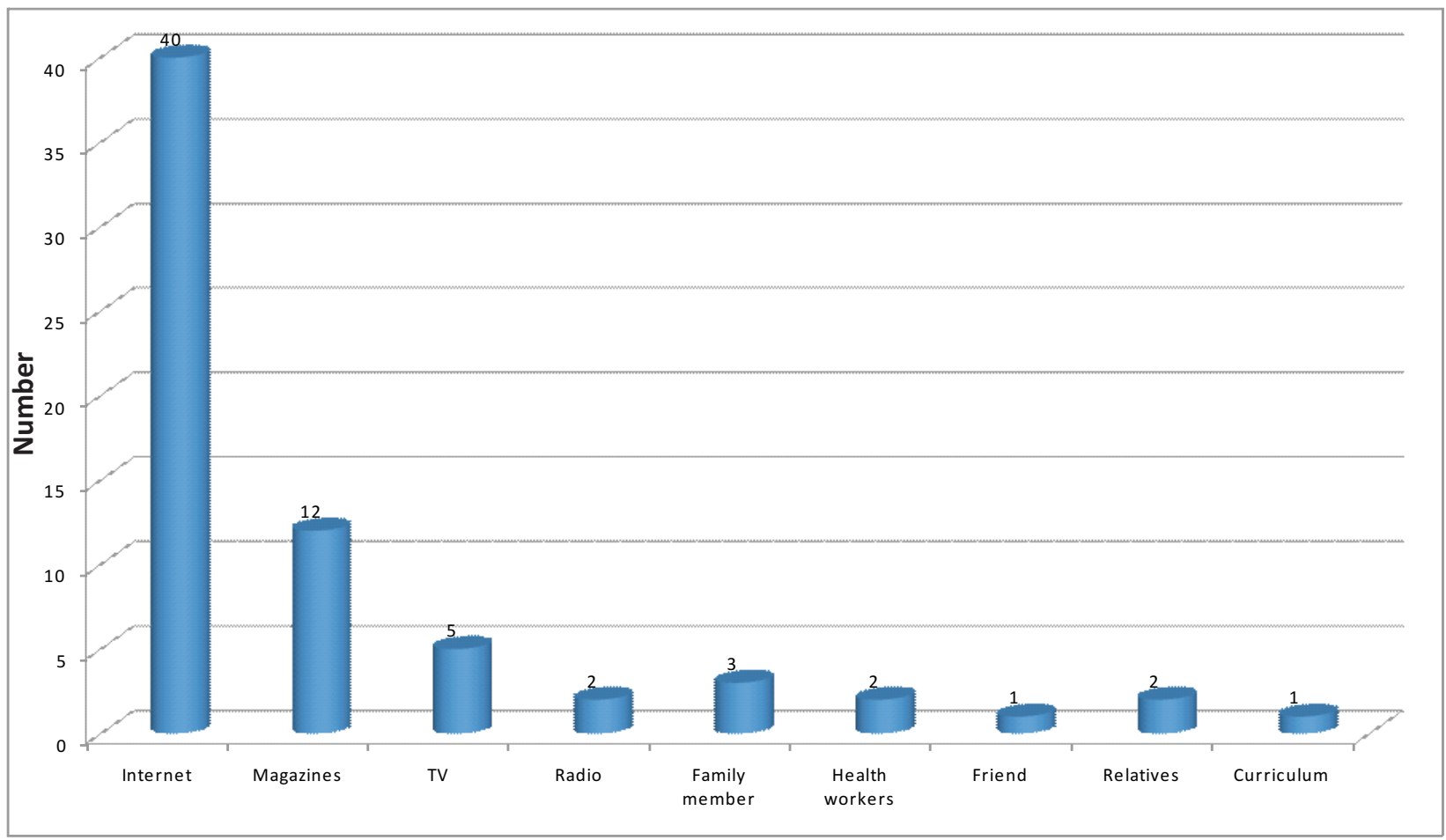

Table 2: Respondents pre and post test knowledge level on BSE

\begin{tabular}{lr|c|c|c} 
Level of Knowledge & $\begin{array}{c}\text { Before Intervention } \\
\text { (Pre-Test) } \\
\text { Frequency }\end{array}$ & $\begin{array}{c}\text { After Intervention } \\
\text { (Post-Test) }\end{array}$ \\
Inadequate $(<50 \%)$ & 46 & 75.4 & 0 & 0 \\
\hline Moderate $(51-75 \%)$ & 14 & 23.0 & 23 & 37.7 \\
\hline Adequate Level $(>75 \%)$ & 1 & 1.6 & 38 & 62.3
\end{tabular}

The changes in knowledge level before and after providing educational intervention programme on BSE has been shown in table 2 . The result reveals that before the program intervention $75.4 \%$ respondents had inadequate knowledge but after the intervention all of participants were able to gain either moderate or adequate level of knowledge. Similarly, only $1.6 \%$ of the respondents had adequate knowledge before intervention and it was significantly increased to $62.3 \%$ after the programme intervention (post-test).

Table 3: Significance test on effectiveness of educational intervention programme on BSE

\begin{tabular}{|l|c|c|c|c|}
\hline \multirow{2}{*}{ Intervention Details } & \multicolumn{3}{|c|}{$\begin{array}{c}\text { Knowledge score of } \\
\text { Students (\%) }\end{array}$} & Test \\
\cline { 2 - 4 } & Mean Score & $\begin{array}{r}\text { Standard } \\
\text { Deviation }\end{array}$ & Statistic & \\
\hline Before Intervention & 33.07 & 16.88 & $\mathrm{t}=23.448$ & $\mathrm{p}<0.001^{* * *}$ \\
\hline After Intervention & 85.14 & 11.98 & $\mathrm{df}=60$ & \\
\hline Difference & 52.07 & 4.9 & & \\
\hline
\end{tabular}

*** Strongly Significant
In table 3, the significance test results on effectiveness of educational intervention programme was illustrated. Paired t-test was applied to test the significance on the score obtained before and after intervention programme on BSE. The observed mean knowledge score before intervention was $33.07 \%$ with standard deviation 16.66 whereas, after the intervention the same figure was reached to $85.17 \%$ with SD 11.98. In the significance test, the t-statistic was obtained 23.448, with $p<0.001$, conforming the educational intervention programme highly significant.

In table 4, the differences in mean knowledge score of the respondents by socio-demographic factors on Breast Self Examination before the program intervention are presented. The variables like age, level of education, religion, ethnicity, respondent's father's and mothers' education, main occupation and monthly income of the family were run to find the significance of variables. Among 8 variables, only the mothers' education found to be significantly related with knowledge score of Breast Self Examination. Hence, it is confirmed that mother's education plays an important role to increase the Breast Self Examination knowledge among the girl adolescents. 
Table 4: Difference in mean knowledge score by selected socio-demographic variables of respondents

\begin{tabular}{|c|c|c|c|c|}
\hline Variables & Category & Number & Mean \pm SD & P Value \\
\hline \multirow[t]{2}{*}{ Age } & 14-16 Years & 21 & $32.49 \pm 19.65$ & $P>0.05$ \\
\hline & 17-19 Years & 40 & $33.38 \pm 14.0$ & \\
\hline \multirow{2}{*}{$\begin{array}{l}\text { Level of } \\
\text { Education }\end{array}$} & Class 11 & 18 & $33.38 \pm 14.5$ & $p>0.05$ \\
\hline & Class 12 & 43 & $33.66 \pm 19.12$ & \\
\hline \multirow{4}{*}{ Religion } & Hindu & 59 & $33.30 \pm 17.11$ & $P>0.05$ \\
\hline & Buddhist & 2 & $26.47 \pm 4.15$ & \\
\hline & Upper High Caste & 34 & $35.12 \pm 18.57$ & \\
\hline & Relatively Advantage & & & \\
\hline \multirow{6}{*}{ Ethnicity } & Janajati & 7 & $29.41 \pm 13.58$ & \\
\hline & Non-Advantage and & & & $P>0.05$ \\
\hline & non Dalit Terai & 9 & $36.60 \pm 17.09$ & \\
\hline & Non-Advantage Janajati & 11 & $26.20 \pm 11.87$ & \\
\hline & Illiterate & 10 & $22.94 \pm 7.56$ & \\
\hline & Literate & 10 & $30.58 \pm 15.38$ & \\
\hline \multirow{5}{*}{$\begin{array}{l}\text { Mother's } \\
\text { Education }\end{array}$} & Primary & 13 & $34.38 \pm 17.45$ & $\mathrm{P}<0.05^{*}$ \\
\hline & Secondary & 20 & $32.64 \pm 17.64$ & \\
\hline & Higher Secondary & & & \\
\hline & and Above & 8 & $47.79 \pm 17.05$ & \\
\hline & Literate & 17 & $26.64 \pm 14.42$ & \\
\hline \multirow{3}{*}{$\begin{array}{l}\text { Father's } \\
\text { Education }\end{array}$} & Primary & 11 & $30.48 \pm 14.36$ & \\
\hline & Secondary & 18 & $34.64 \pm 16.24$ & $P>0.05$ \\
\hline & Higher Secondary and Above & 15 & $40.39 \pm 19.99$ & \\
\hline \multirow{3}{*}{$\begin{array}{l}\text { Mother's } \\
\text { Occupation }\end{array}$} & Business & 5 & $45.88 \pm 20.96$ & \\
\hline & Service & 6 & $29.41 \pm 15.78$ & $P>0.05$ \\
\hline & Housewife & 50 & $32.23 \pm 16.39$ & \\
\hline \multirow{4}{*}{$\begin{array}{l}\text { Father's } \\
\text { Occupation }\end{array}$} & Farmer & 11 & $24.59 \pm 13.36$ & \\
\hline & Service & 21 & $36.41 \pm 19.74$ & $P>0.05$ \\
\hline & Business & 29 & $33.87 \pm 15.21$ & \\
\hline & NRS $5000-10000$ & 8 & $29.41 \pm 12.17$ & \\
\hline \multirow{4}{*}{$\begin{array}{l}\text { Income of } \\
\text { Family per } \\
\text { month }\end{array}$} & NRS 10001 - 15000 & 10 & $28.23 \pm 16.35$ & \\
\hline & NRS 15001 - 20000 & 18 & $33.66 \pm 18.02$ & $P>0.05$ \\
\hline & NRS 20001 - 25000 & 19 & $35.60 \pm 18.23$ & \\
\hline & NRS 25001 and above & 6 & $36.27 \pm 18.00$ & \\
\hline
\end{tabular}

* Significant (paired t-test was used at $5 \%$ level of significance)

\section{DISCUSSION}

Knowledge on BSE was assessed through self-administered structured questionnaire. Among the 61 respondents, majority of respondents were from age group 17-19 years, and the mean age was $16.62 \pm 1.19$ years. Majority of respondents $(70.5 \%)$ were from grade 12 and Hindu religion was followed by $96.7 \%$.
Out of total respondents, $82 \%$ of respondents have not heard about BSE and the major source of information was media during the baseline (pre-test). Similarly, $75.4 \%$ of the respondents have inadequate knowledge before the intervention but after the intervention package all participants were gained either moderate or adequate level 
of knowledge. Similarly, only $1.6 \%$ of the respondents have adequate knowledge before intervention and it was significantly increased to $62.3 \%$ after the intervention. The socio-demographic variables like age, level of education, religion, ethnicity, respondent's father's and mothers' education, mothers' and fathers' occupation and monthly income of the family were run to find the association of variables with knowledge score before the intervention, however, only the respondents' mothers' education found to be significantly related with knowledge score of Breast Self Examination.

Findings of this study were supported by the study conducted by Shalin et al (2011). The study was conducted to determine the effectiveness of structured teaching programme on BSE among school going girls. They reported, only $5 \%$ had good knowledge and $22.5 \%$ had poor knowledge before intervention and after the intervention, none of the students had poor (inadequate) knowledge and $85 \%$ had good (adequate) knowledge. ${ }^{12}$ They also found the intervention effective.

Similar Study conducted by Tuna A et al. on effectiveness of online education on BSE shows that $14 \%$ of respondents had average knowledge on BSE before intervention (structured teaching program) and after structured teaching programme $77.4 \%$ respondents had good knowledge level. ${ }^{13}$

A study conducted in Egypt by I.B.f. Kharboush et al on raising the Breast Health awareness among 486 women during 2009-2010 also supports this finding. Health education sessions were carried out to educate the women on BSE and the findings indicated a significant increase in the mean knowledge score, in pre-test 64 had knowledge regarding Breast Self Examination and 422 had no knowledge and in post intervention 485 had good knowledge. ${ }^{14}$

The findings were also supported by the similar study conducted by Shalini et al (2011), in Udupi district-India. The study was conducted to determine the effectiveness of structured teaching programme on BSE among school going girls. Mean knowledge score in pre-test was 27 whereas in post-test it was $50, t=12.46, d f=39$ and $p<0.05$ indicating the structured teaching program was effective in improving the knowledge on BSE among school going girls. ${ }^{12}$

Another interventional study conducted by Tuna A et.al (2014) on effectiveness of online education on BSE supports the above findings which showed $p<0.00$ and overall increment of knowledge $63.4 \%$, indicating teaching program was effective in improving the knowledge on BSE. ${ }^{13}$
Similar interventional study conducted by Ramalingam $S$ et al (2012) on knowledge and attitude about breast cancer and BSE among school teachers in an urban area of Coimbatore among 34 teachers between age group 22-58 years also supports the above findings which showed that mean pre-test scores was 16.75 and post-test 22.50 respectively $(p<.0001) .{ }^{15}$

An interventional study conducted by Shalin et al (2011) to determine the effectiveness of structured teaching programme on BSE among school going girls Udupi district India revealed the similar findings, where, respondent's exposure to mass media was positively related with BSE pre-test knowledge score $(p<0.05)$. However, the education level of respondents was not related which also support findings of this study. ${ }^{12}$

Another cross-sectional survey done by Aniebue PN et al. (2008) on awareness of breast cancer and Breast Self Examination among four hundred and twenty eight female secondary school teachers in Enugu Metropolis, South Eastern Nigeria revealed no significant relationship between age, educational attainment and knowledge of BSE which strongly supports findings of this study. ${ }^{16}$

An interventional study conducted by Moustafa DG on Effect of a Breast-Self Examination (BSE) educational intervention among 180 female university students ${ }^{17}$ showed that mothers' occupation were significantly related with knowledge level of BSE which is slightly contradictory to the findings of this study.

This study is able to cover only 61 adolescent girls for the intervention package; large scale study in similar intervention in diverse setting can give better generalization.

\section{CONCLUSION}

The educational intervention programme on BSE was found to be highly effective as the knowledge score was significantly increased after intervention of the package among higher secondary school girls. Among the various socio-demographic variables only mothers' education found to be effective with pre-test knowledge score. Therefore, the government and other health agencies should focus to apply educational intervention package for breast self examination along with focus to increase the education level among women.

\section{ACKNOWLEDGMENT}

We are thankful with all girls participants of Meryland School, Biratnagar.

\section{CONFLICT OF INTEREST}

None 


\section{REFERENCES}

1. Bray F, Song J R, Masuyer E and Ferlay J. Global estimates of cancer prevalence for 27 sites in the adult population in 2008. International journal of cancer. 2013.132(5).p: 1133'1145. http://onlinelibrary.wiley. com/doi/ 10.1002/ijc. 27711/abstract .(12/4/2015).]

2. WHO (2012); World Health Statistics 2012. World Health Organization, Geneva 2012;p35-73.

3. Agarwal G, Ramakant P. Breast Cancer Care in India: The Current Scenario and the Challenges for the Future. Karger medical and scientific publisher. 2008;3 (1). p:21-27 http://www. karger.com/ Article/Pdf/115288. (12/02/2015).

4. Pradhananga KK, Baral M, Shrestha BM. Multi-institution hospitalbased cancer incidence data for Nepal: an initial report.Asian Pac J Cancer Prev. 2009 Apr-Jun;10(2).p:259-62. DOI 10. 1186/s12992-0150119-7.(19/12/2015)

5. Loh Y I, Chew S L. Awareness and practice of breast self examination among Malaysian women with breast cancer. Asian Pacific journal of cancer prevention: APJCP. 2011 jan; 12(1).p:199-202.https://www. researchgate. net/ publication/51074253_.(4/12/2015)

6. Brunner LS, Suddarth DS. $12^{\text {th }}$ edition. Textbook of medical-surgical nursing. Philadelphia: J.B. Lippincott Company, 2010.p:1473-1475

7. Sharma T, Agrawal CS, Agrawal A. Validating breast self examination as screening modalities for breast cancer in eastern region of Nepal: a population based study Kathmandu Univ Med J (KUMJ). 2008 JanMar;6(1).p:P89-93. http://www.ncbi.nlm.nih.gov/ pubmed/18604121 (04/12/2015).

8. Al-Naggar RA, Al-Naggar DH, Bobryshev YV, Chen R, Assabri A. Practice and barriers toward breast self-examination among young Malaysian women .Asian Pac J Cancer Prev. 2011;12(5).p:1173-8. http://www. ncbi.nlm.nih.gov/ pubmed/21875261 (12/2/2015).

9. Ahmed B A . Awareness and Practice of Breast Cancer and Breast-self Examination among University Students in Yemen. Asian Pacific J Cancer Prev.2010;10(1):p.101-105. http://www.apocpcontrol. org/ paper_file/issue_abs/Volume 11_No1/ 101\%20c\%20 Ahmed.pdf $(12 / 02 / 2015)$
10. Naomi N. Modeste, Drayton VLC, Montgomery S. Barriers to early detection of breast cancer among women in a Caribbean population . Rev Panam Salud Publica/Pan Am J Public Health.1999.5(3).p:152156. http:// www. scielosp.org/pdf/rpsp/v5n3/a3.pdf. (02-12-2015)

11. Tripathi N, KadamYR, Dhobale RV, and Gore AK. Barriers for early detection of cancer amongst Indian rural women. South Asian J Cancer. 2014 Apr-Jun; 3(2).p: 122-127. http://www. ncbi. nlm.nih.gov/pmc/ articles/ PMC4014643/.(02-12-2015)

12. Shalini, Varghese D and Nayak M. Awareness and Impact of Education on Breast Self Examination Among College Going Girls. Indian J Palliat Care. 2011 May-Aug; 17(2): 150-154. doi: 10. 4103/0973-1075.84538. (5/10/2015)

13. Tuna A, Avdal EU, Yucel SC, Dal NA, Dicle A, Ozkan A et al. Effectiveness of online education in teaching breast self- examination. Asian Pac J Cancer Prev. 2014;15(7):3227-3. http:// www.ncbi.nlm.nih.gov/ pubmed/24815475. (2015/07/27).

14. Kharboush IBF. Raising the Breast Health Awareness amongst Women in an Urban Slum Area in Alexandria, Egypt. Breast Care (Basel). 2011 Oct; 6(5).p: 375-379. doi: 10.1159/000331311. (5/13/2015).

15. Ramalingam S, S Nivedhitha, Pon D, PMadhurima, Poonguzhali R.The Asian Students' Medical Journal . Knowledge and Attitude about Breast Cancer and Breast Self Examination among school teachers in an urban area of Coimbatore.Asian Students Medical Journal. 2012;11(1).p:1-5

16. Aniebue PN, Aniebue UU. Awareness of Breast Cancer and Breast Self Examination Among Female Secondary School Teachers in Enugu Metropolis, South Eastern Nigeria. International Journal of Medicine and Health Development. 2008;13(2). p:105-110. http://www. ajol.info/index.php/jcm/article/view/10591. (5/13/2015).

17. Moustafa DG, Abd-Allah ES, Taha NM; Effect of a Breast-Self Examination (BSE) Educational Intervention among Female University Students. American Journal of Nursing Science. August 2015; 4(4). p:159-165.DOI: 10. 11648/j.ajns. 20150404.13. (10/01/2016) 